\title{
Editorial
}

\section{Looking back at 50 years Acta Politica}

Acta Politica (2016) 51, 1-12. doi:10.1057/ap.2015.15; published online 23 October 2015

\section{Introduction}

Acta Politica - Tijdschrift voor Politicologie was first published in 1965/1966, ${ }^{1}$ under the auspices of the Nederlandse Kring voor Wetenschap der Politiek (NKWP, Dutch Political Science Association). The then president of the NKWP, Professor L.G.A. Schlichting of the Catholic University of Nijmegen, explained in a preface that the association, which had been founded in 1950, aimed at addressing a broader audience. In the Netherlands, academic programmes in political science had started only after World War II. By 1965, political science had 'become increasingly attractive and ... there are several hundreds of graduates who took political science as a major or minor' (Schlichting, 1966, p. 1; translation KA/IvB). These considerations also justified the expectation that a scientific journal of its own would be economically viable.

The first volume of 294 pages was published in a single cover, as the editors wanted to 'provide an overview of the versatility that characterizes the study of political science, also in the Netherlands' (ibid.). The volume contained contributions by a large number of Dutch political scientists, including Hoogerwerf, Daudt, Daalder, Lipschits, Kuypers, Baehr and De Swaan. It also contained a bibliography of publications that are relevant for political scientists, and English-language summaries of all contributions.

After this first volume, almost 50 additional volumes, or 200 separate issues have been published so far. What has changed over this half century, and what has remained constant? Below, we discuss this by focusing on a few milestones. We stop by: the transition to English, the change of publishers, the changing editorial model, the inclusion in the Web of Science (WoS), changes in the subject fields of published articles, and in the topics of special issues. Finally, we briefly introduce the anniversary collection.

\section{Milestones}

\section{Towards an English-language journal}

During the first 30 years of its existence (1965-1996), Acta Politica has always published a mix of Dutch- and English-language contributions. For a long time, 
mixing Dutch- and English-language contributions in a single issue was not seen as a problem whatsoever. The Dutch articles made the journal easily accessible, also to interested readers outside academia. The optional use of English made Acta Politica attractive for Dutch scholars aiming at an international audience, and to foreign scholars desiring to publish on, or just in the Netherlands. The mix worked out well for many years. But with the internationalization of political science and the rise of academic research management in the 1980s and 1990s, the editors felt the need to choose for either Dutch or English. In the last issue of 1996, the editorial team stated its view on the future of the journal:

From the 1970s onwards, the number of specialized and non-specialized political science journals has proliferated. From the outset, many of the new journals were internationally oriented. All in all, the number of possible outlets for political science research in the Netherlands and Europe has increased enormously. (...) [A] certain lack of focus, plus the combination of global and parochial outlooks ... did not favour the position of [Acta Politica] in a world with growing competition for quality. (Aarts et al, 1996, p. 342).

Using one language - English - was seen as an essential enhancement of the journal's profile. But the transition to English was controversial. A part of the Dutch political science community opposed it, out of a fear for losing focus and relevance. Therefore, the editorial team also formulated an editorial policy - the first since Schlichting's remarks in the first issue, quoted earlier:

Acta Politica will continue to be a general, non-specialized, journal of political science. (...) At the same time, the journal aims at maintaining its position as the most prominent forum for publications pertaining to politics in the Netherlands, broadly defined. (ibid, p. 343)

The transition was controversial but also successful. The dual aims of remaining both a general journal and a forum for work on the Netherlands (or better: the Low Countries) have been accomplished, even if this requires some balancing on the part of the editors. And the transition to English turned out to be the first step in a series towards a more professional and qualitatively better journal.

\section{From Boom to Palgrave Macmillan}

The second milestone followed soon after the transition to English. Boom is a reputed Dutch publishing house, established in 1841 in Meppel, and presently still a family company. Acta Politica started as a joint activity of the Dutch Political Science Association and Boom. The relationship was for a long time mutually beneficial. A subscription to Acta Politica was included in the NKWP membership; in addition subscriptions were sold to a variety of libraries 
(academic and public) in the Netherlands and abroad. A journal still was a product printed on paper.

Although all parties involved (Boom, editorial team, NKWP) were quite happy with the arrangements, the switch to English in 1996 revealed a weak spot in their relationship. Boom was not an international academic publishing house, and the editorial team and NKWP started to explore the possibility of moving to another publisher. There was no shortage of attention by publishers. The name of the journal was (and is) attractive, its reputation well-established, and the potential for international marketing seemed great.

Editors and NKWP entered negotiations with the British publishing house Palgrave Macmillan, and soon reached an agreement about the transfer of Acta Politica from Boom to Palgrave by 2003. In the contract of NKWP and Palgrave, a joint ownership of the journal is regulated. Palgrave publishes a variety of journals, also in the field of political science, and is therefore in a better position to bring Acta Politica to the attention of university libraries worldwide, also in a web-based format and as part of a package of scientific journals. A journal web page was created as well, with information about current, archived and future contributions. For promotional purposes, selected articles were made available on the web page at no cost. More recently, this web page also hosts from time to time virtual special issues - collections of articles with a common theme, which were published in different issues of Acta Politica (like the anniversary collection). Less visible for the readers but extremely important for the editors, contributors and reviewers is the extensive editorial system that Palgrave provides. All submissions are handled through the web, and the editors have almost endless opportunities for retrieving information, monitoring progress, addressing reviewers, and so on.

\section{From editorial team to editors}

For a long time Acta Politica was edited by a team of editors. The word 'team' here has to be taken very seriously. Only relatively recently the current practice evolved of two co-editors who divide most of the work between them.

In Table 1, all editors of Acta Politica in the past half century have been listed. From the start in 1965/1966 until 2000, the editorial team consisted of mostly 4-7 persons. One of these served as secretary, to whom manuscripts were sent which were subsequently distributed in the team and discussed by all at an editorial meeting. Another editor served as book review editor, who would send out new books for review. The editorial team met in principle every three months, and the secretary communicated with the publisher about the contents of the next issue. External reviewers hardly played a role until the 1990s. These were consulted only when a submitted paper required very special expertise - which was in fact an 
Table 1: Chronological overview of editors

\begin{tabular}{|c|c|c|}
\hline Name & Started & Stopped \\
\hline Peter R. Baehr & 1966 & 1971/1 \\
\hline Nico Cramer & 1966 & $1972 / 1$ \\
\hline G.H. van Es & 1966 & 1972/1 \\
\hline Andries Hoogerwerf & 1966 & 1970/1 \\
\hline Lucas van der Land & 1966 & $1972 / 1$ \\
\hline D. Boonstra & $1970 / 2$ & $1974 / 2$ \\
\hline L.P.J. de Bruijn & $1970 / 2$ & 1976/1 \\
\hline Jan van Putten & $1971 / 1$ & 1976/1 \\
\hline Joop De Vree & $1971 / 2$ & $1980 / 4$ \\
\hline R.P. van der Helm & $1972 / 2$ & 1976/1 \\
\hline Ben J.S. Hoetjes & $1972 / 2$ & $1983 / 2$ \\
\hline Koen Koch & $1975 / 3$ & $1990 / 3$ \\
\hline Joop van den Berg & $1976 / 2$ & $1981 / 3$ \\
\hline Otto Schmidt & $1976 / 2$ & $1988 / 4$ \\
\hline H.W. Blom & $1977 / 1$ & $1979 / 3$ \\
\hline Percy B. Lehning & $1979 / 4$ & $1990 / 3$ \\
\hline Rudy Andeweg & 1985/1 & $1994 / 3$ \\
\hline Cees van der Eijk & $1985 / 1$ & $1992 / 2$ \\
\hline Bob Lieshout & $1985 / 1$ & $1995 / 2$ \\
\hline Wil Hout & 1989/1 & $2000 / 2$ \\
\hline Selma Sevenhuijsen & 1990/4 & $1993 / 3$ \\
\hline Kees Niemöller & $1992 / 3$ & $1996 / 4$ \\
\hline Kees Aarts & $1993 / 4$ & $2000 / 2$ \\
\hline Jet Bussemaker & $1993 / 4$ & $1998 / 3$ \\
\hline Jan van Deth & $1993 / 4$ & $1996 / 4$ \\
\hline Hans Oversloot & $1993 / 4$ & $2000 / 2$ \\
\hline Kees van Kersbergen & 1997/1 & $2000 / 2$ \\
\hline Holli A. Semetko & 1997/1 & $2000 / 2$ \\
\hline Huib Pellikaan & $1998 / 3$ & 2003/1 \\
\hline Bertjan Verbeek & $1998 / 3$ & $2003 / 4(2006 / 4)$ \\
\hline Renske Doorenspleet & $2001 / 3$ & $2003 / 1$ \\
\hline Hans Keman & $2003 / 4$ & $2007 / 4$ \\
\hline Marc Hooghe & $2003 / 4$ & $2010 / 2$ \\
\hline Kees van Kersbergen & $2008 / 1$ & $2010 / 4$ \\
\hline Kees Aarts & $2010 / 3$ & $2015 / 3$ \\
\hline Ingrid van Biezen & $2011 / 1$ & - \\
\hline Rens Vliegenthart & $2015 / 4$ & - \\
\hline
\end{tabular}

argument against publication. This model worked fine as long as the number of submission remained modest, which was the case.

The first crack in the idea that the editors formed a collectivity occurred in 1996, when for the first time the academic affiliations of the editors were included in the cover materials (before, only the names were listed). The next step was taken in 2000. 
A organizational model with one managing editor, a book reviews editor and an 'editorial advisory board' was implemented. In addition, the traditional editorial board was renamed as 'international advisory board'. In 2001, an 'assistant managing editor' was added. Soon after the transfer to Palgrave in 2003, the model with two editors on an equal footing, each with his or her own term, emerged. The book review editor was listed separately from 2004 onwards. Bertjan Verbeek served as book review editor until 2007/1, when Wouter van der Brug took over. He was succeeded in 2010/1 by Fraser Duncan. In 2008, the two advisory boards were merged into one.

From Table 1, a list of the longest serving editors is easily obtained. That list is topped by Koen Koch, who was an editor for 15 years (1975-1990). A select group of persons has edited Acta Politica for 10 years or more. In addition to Koch, this group comprises Otto Schmidt, Ben Hoetjes, Percy Lehning, Bob Lieshout, Wil Hout and Kees Aarts. But the length of an editorship does not necessarily coincide with its importance. After the founding group that started in 1966, the most important transitions occurred with Wil Hout, Huib Pellikaan, and Hans Keman at the helm.

In 2003, the new post of editorial secretary was introduced, the person keeping track of all manuscripts, who also is the linking pin between the publisher and the editors. Margiet Lambert of the Free University Amsterdam was the first editorial secretary, serving from 2003/4 until 2010/4. She was succeeded by Janine van der Woude (2011/1-2012/2) and Seeta Autar (2012/3-2014/2), both at the University of Twente. Since 2014/3, Veerle van Doeveren (Leiden University) acts as editorial secretary.

\section{Inclusion in web of science}

After the transfer to Palgrave Macmillan, the editors and the publisher jointly applied for inclusion of Acta Politica in the ISI (now: Thomson Reuter's) WoS ranking. Acta Politica received its first citation impact score for 2007: 0.605, or rank 41 among 93 journals in political science. After 2007, the number of political science journals in WoS has increased dramatically, to 161 in 2014. Figure 1 shows the development of the impact factor since 2007. Impact factors can and do show considerable variation from year to year, as the figure shows. In terms of ranking, Acta Politica has a stable position (with one exception in 2012) among the highest 30-50 per cent of political science journals. The most recent impact factor is also the highest so far (1.025), ranking Acta Politica as \#54 among 161 journals in political science.

The number of submitted manuscripts has shown a steady increase since the transition to English in the 1990s. In the most recent years, this number is close to 100 per year. Most manuscripts are sent out for peer review, and editorial decisions are almost always based on two or more reviews. The system of double-blind peer 


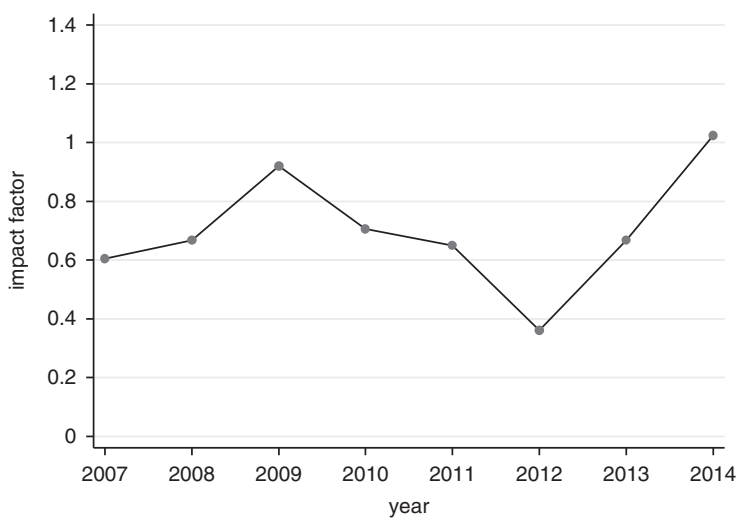

Figure 1: Journal impact factor since 2007.

reviews, on which most journals depend, functions thanks to the voluntary services provided by the peers. It is amazing to see the efforts that our reviewers put into the reviewing process, resulting in often very extensive, detailed and constructive criticisms. Partly in order to protect the system of double-blind reviewing, the number of desk rejections has increased in the past few years. A growing number of manuscripts are rejected by the editors before review, when the editors consider it highly unlikely that (a revised version of) the manuscript will eventually be publishable in Acta Politica, for reasons of low quality or because of the topic (too narrow, too many recent publications in Acta Politica about the topic).

\section{Changes in subjects of published articles}

As a general journal of political science, Acta Politica publishes work - as articulated by the current mission statement - that includes all sub-areas of the discipline, including Dutch and comparative politics, international relations, political theory, public administration, and political communication. Indeed, as can be seen from Table 2, throughout the existence of the journal, contributions to Acta Politica have covered the entire breadth of the discipline. What is also apparent, however, is that some areas of inquiry are better represented than others, and that some noticeable shifts of attention have occurred over the past 50 years, in particular since the transition to English as the journal's official language.

Table 2 shows the percentage of contributions to Acta Politica over its entire history, sub-divided by decade. The contributions are roughly divided into distinct 
Table 2: Overview of subject field of published articles, percentages by decade

\begin{tabular}{lccccc}
\hline & $1966-1975$ & $1976-1985$ & $1986-1995$ & $1996-2005$ & $2006-2015$ \\
\hline Political Science (the discipline) & 14.1 & 4.8 & 1.1 & 0 & 0 \\
Public administration & 6.3 & 6.6 & 5.3 & 0 & 0.6 \\
International relations & 7.9 & 4.8 & 9.5 & 3.1 & 1.8 \\
Political theory & 4.2 & 10.8 & 12.2 & 16.6 & 4.8 \\
Rational choice & 0.5 & 4.2 & 8.5 & 0 & 0 \\
Politics and law & 1 & 0 & 2.1 & 0 & 0 \\
Politics and policy-making & 8.9 & 12 & 4.2 & 1.2 & 1.8 \\
Europe/EU & 0 & 2.4 & 1.6 & 9.2 & 17.6 \\
US/Russia & 2.1 & 0.6 & 1.6 & 3.1 & 1.8 \\
Political economy & 2.6 & 4.8 & 1.6 & 5.5 & 7.3 \\
Voting behaviour & 19.9 & 21.1 & 12.7 & 14.7 & 9.7 \\
Political parties & 5.8 & 5.4 & 6.9 & 9.8 & 6.1 \\
Political institutions & 9.9 & 6.6 & 6.3 & 9.2 & 21.8 \\
Political participation & 3.1 & 1.2 & 2.6 & 0 & 4.8 \\
Local politics & 1.6 & 3.6 & 0.5 & 2.5 & 0 \\
Consociationalism & 0.5 & 5.4 & 2.1 & 10.4 & 3 \\
Democracy & 4.2 & 1.8 & 4.8 & 6.7 & 6.7 \\
Politics and media & 1 & 0.6 & 1.1 & 0.6 & 3 \\
Miscellaneous & 6.3 & 3 & 15.3 & 7.4 & 9.1 \\
\hline
\end{tabular}

areas (public administration, international relations, political theory, rational choice, politics and law, political economy, (domestic) politics and policy-making) of the discipline. The areas of Dutch and comparative politics in practice show a considerable overlap, and are sub-divided into various thematic areas that have tended to receive prominent attention over the years, including, most noticeably, issues such as voting behaviour, political parties and political institutions.

In the first three decades, Acta Politica focused more attentively, albeit not exclusively, on the Netherlands. This can be seen, among others, from the category 'politics and policy-making'. There we primarily find discussions on domestic policies and legislation, with some specific themes dominating particular periods. In the decade between 1976 and 1985, for instance, we encounter a substantial number of contributions on the decolonization process in the Dutch East Indies. 'Consociationalism' is another typically Dutch (and Belgian) theme which regularly appeared in Acta Politica, although interestingly more prominently after the transition to English in 1996 and with articles not necessarily focusing only on the Dutch and Belgian cases. Also noticeable about the early years of Acta Politica is the relatively high share of articles dedicated to the profession, with discussions about the state and nature of the discipline of political science in the Netherlands and elsewhere comprising a substantial part of the contributions in the first decade of the journal in particular. 
In terms of the various sub-disciplines other than Dutch and comparative politics, political theory is relatively well-represented, with the popularity of theories of deliberative democracy contributing to most of this field in the period since 1995. The contributions from international relations and public administration are relatively modest by comparison. Rational choice enjoyed a brief highpoint in the decade between 1985 and 1995, only to have disappeared from the journal altogether in the period thereafter.

In absolute and relative terms, voting behaviour, which comprises public opinion research, issue voting and positioning as well as more traditional electoral research, is clearly the one of the most popular themes, although its share has diminished somewhat over the years. In addition, while contributions in the early years typically focused on the Netherlands, with 47 out of 73 articles between 1966 and 1985 discussing the Dutch case, in subsequent years scholars writing on the subject have tended to focus their attention more widely and also comparatively. Political institutions broadly understood, including electoral systems, government structures, cabinets and parliaments, have always featured prominently as well, with a noticeable rise in attention for the (Dutch) electoral system in recent years. Political parties have similarly been a consistently prevalent topic. The rise of extreme right wing and later populist parties, in both Belgium and the Netherlands, accounts for a large part of its popularity, in particular from the mid-1980s onwards. The European Union scarcely featured in the early years of the journal, with only seven articles on the subject between 1966 and 1995, but has clearly become a more central focus of attention since then.

\section{Special issues}

A special issue of a journal offers an opportunity to publish a coherent set of articles on a timely subject. Acta Politica has published special issues in every decade of its existence so far. However, the topics and the frequency of special issues appear to have shifted over the years (Table 3 ).

Disregarding the first volume, in the first 10 years two special issues have been published. The first of these focused on the relationship between political science and political practice, while the second provided an extensive documentation of the incisive conflicts within and about political science at the University of Amsterdam in the early 1970s, which made a deep impression on all those involved. The first substantive special issue was published in 1983, and was devoted to the first 10 years of the Dutch national election study (NKO).

In the 1980s four more special issues were published, devoted to a variety of topics: a discussion of the theory of consociationalism, a 'Festschrift' for Hans Daudt, a debate on the methods and results of the first nationwide research assessment, and an overview of modern political theory (the latter even required two issues). 
Table 3: Overview of special issues

Issue Guest editors Title

1972/2 NA

1973/4 P.R. Baehr and G.H. Scholten

1983/2 Cees van der Eijk and Kees Niemöller

1984/1 Rinus van Schendelen

1986/3 Hans Daalder

1988/1 NA

1988/ Mark Bovens, Percy Lehning, Robert Lieshout,

2-3 Hans Oversloot

1992/1 Wil Hout and Robert Lieshout

1993/3 Wil Hout and Rudy Andeweg

1996/4 NA

1999/ Kees Aarts and Holli A. Semetko

2-3

2002/ Jürg Steiner and Thomas Ertman

$1-2$

2003/1 Wouter van der Brug and Huib Pellikaan

2004/4 Marc Hooghe and Dietlind Stolle

2005/ André Bächtiger and Jürg Steiner

2-3

2006/ Henk van der Kolk and Jacques Thomassen

$2-3$

2008/ Hans Keman

$2-3$

2010/ Tanja A. Börzel

$1-2$

2014/1 Natalia Timus and Simon Lightfoot

2014/4 Ruth Dassonneville and Michael S. Lewis-Beck
Title

Politikologie en politieke problemen

Conflicten over de politicologie aan de Universiteit van Amsterdam

In het spoor van de kiezer: Aspecten van 10 jaar kiesgedrag

Consociationalism, pillarization and conflict-management in the Low Countries

Democratie, politiek gedrag en machtsverhoudingen in Nederland: Enige thema's uit het politicologisch werk van $\mathrm{H}$. Daudt

Sterkte/zwakte analyse sociologie, politicologie en bestuurskunde

Hedendaagse politieke theorie 1 and 2

Does theory matter? Dutch contributions to the study of international relations

De Nederlandse politiek: Sleutelen aan het systeem

Thirty years of change in Dutch and European politics (anthology)

The 1998 Dutch election in perspective

Consociationalism and corporatism in Western Europe: Still the politics of accommodation?

Electoral revolt or continuity? The Dutch parliamentary elections 2002 and 2003

Youth, politics and socialization

Empirical approaches to deliberative democracy 1 and 2

The Dutch electoral system on trial 1 and 2

Dutch politics

Civil society on the rise? EU enlargement and societal mobilization in Central and Eastern Europe

Europarties between 'deepening' and 'widening'

The economic voter and the economic crisis 
The 1988 special issue on the research assessment exercise was the last one devoted to political science as an institution. From the 1990s onwards, the special issues have all been devoted to a substantive theme or problem (with the exception of an anthology in 1996/4). This is an understandable and perhaps even natural development in the context of the growing professionalization of political science.

Before 1999, no special issue was edited by non-Dutch political scientists. In contrast, the most recent three special issues were all edited by non-Dutch colleagues.

\section{The Anniversary Collection: Electoral Volatility and Party Change in the Low Countries}

In order to celebrate 50 years of Acta Politica, the editors have assembled a special online anniversary collection, with the aim to give readers a taste of the publications in Acta Politica over the past 12 years, since 2003 when Palgrave Macmillan became our publisher. We have restricted ourselves to this relatively recent period as a previous anthology, published in 1996, covered the first three decades of Acta Politica (29:4). The six articles that we selected, all deal with aspects of the rise (and decline?) of 'new politics' in the Netherlands and Belgium in these 12 years. It was tempting to come up with a selection of articles that, for example, we as editors liked best, or articles that have been cited most frequently thus far. The former criterion would be all too subjective while the latter would have led to an incoherent anniversary collection.

The first issue of Acta Politica published by Palgrave Macmillan was a special issue on the 2002 parliamentary election in the Netherlands. The election campaign of 2002 and the result on 15 May had shocked many observers. The enthusiasm for (and aversion to) Pim Fortuyn, who was assassinated nine days before the election, brought to light unanticipated and seemingly new political conflicts. Huib Pellikaan, Tom van der Meer and Sarah de Lange position the rise of Fortuyn and his 'new politics' in the ideological developments of the 1980s and 1990s in the Netherlands. Their analysis of party programmes and the changes therein between 1998 and 2002 provides an innovative framework for understanding the opportunity structure for political newcomers. Meanwhile, in Flanders the anti-immigrant party Vlaams Blok had already been electorally very successful for years but was completely isolated by the other parties. In the same period the Walloon Front National failed to make a major electoral breakthrough. Hilde Coffé shows that the different electoral fortunes of Vlaams Blok and Front National cannot be simply attributed to individual-level factors in Flanders and Wallonia. Anti-immigrant feelings are even stronger in Wallonia than in Flanders. By implication, those differences must have historical, cultural and political roots.

Eric Bélanger and Kees Aarts revisit the sources of Fortuyn's rise and the success for the LPF party in the Dutch 2002 election. They present this success as typical for 
a niche party, by connecting it to the issue positions taken by the LPF and to the reservoir of political discontent that its voters had accumulated in previous years. Peter Mair addresses the question how exceptional recent Dutch elections have been in terms of electoral volatility. In a comparison that stretches 16 countries and 50 years, he shows that volatility in the Netherlands is extremely high by any standard. He argues that the cause is to be found in the relative openness of the Dutch electoral system for newcomers.

Tom van der Meer, Rozemarijn Lubbe, Erika van Elsas, Martin Elff and Wouter van der Brug analyse the sources of electoral volatility in detail, on the basis of a (self-selective) panel study of Dutch citizens between 2006 and 2010. They show, most importantly, that voters typically change their party preference within, not between, two larger blocks of parties (one on the left, the other on the right, with D66 as the bridge between these blocks). Teun Pauwels, finally, looks into the electoral decline in Flanders of Vlaams Belang, the heir of Vlaams Blok. After years of political quarantine, other newcomers - Nieuw-Vlaamse Alliantie ( $N$-VA and Lijst Dedecker (LDD) - stepped in and succeeded in appropriating the issues that for a long time belonged to the Flemish extreme right. Pauwels argues that voters turned to these less radical alternatives because the isolated Vlaams Belang consistently failed to deliver on its promises.

\section{New Editorial Team}

From issue 50.4 Kees Aarts has stepped down as co-editor in order to take up the chairmanship of the Dutch Political Science Association (NKWP - De Kring). We are happy to introduce Rens Vliegenthart as a new co-editor for Acta Politica. Rens is presently professor for Media and Society at the Amsterdam School of Communication Research (ASCoR), University of Amsterdam (UvA). Rens is also a member of the Young Academy of the Royal Netherlands Academy of Arts and Sciences (KNAW) and co-chair of the political communication division of NeFCA, the Netherlands-Flanders Communication. As a co-editor, Rens will work together with Ingrid van Biezen, who started in 2011.

\section{Note}

1 The first volume was dated '1965/1966' but technically this volume was published only in 1966.

\section{References}

Aarts, K., Bussemaker, J., Hout, W., Oversloot, H. and Semetko, H. (1996) Editorial: Towards a new Acta Politica. Acta Politica 31(4): 339-349.

Schlichting, L.G.A. (1966) Verantwoording. Acta Politica 1: 1-2. 
Kees Aarts

Department of Public Administration, University of Twente, The Netherlands.

E-mail: c.w.a.m.aarts@utwente.nl

Ingrid van Biezen

Department of Political Science, Leiden University, Leiden, The Netherlands. E-mail: i.c.van.biezen@fsw.leidenuniv.nl 